\section{AIDS incidence and mortality in injecting drug users: the AjUDE-Brasil II Project}

\author{
Incidência de AIDS e mortalidade em usuários \\ de drogas injetáveis: Projeto AjUDE-Brasil II
}

Mauro Nogueira Cardoso ${ }^{1}$ Waleska Teixeira Caiaffa ${ }^{1}$ Sueli Aparecida Mingoti 2 Projeto AjUDE-Brasil II 3

\footnotetext{
1 Faculdade de Medicina Universidade Federal de Minas Gerais, Belo Horizonte, Brasil. 2 Instituto de Ciências Exatas, Universidade Federal de Minas Gerais, Belo Horizonte, Brasil. 3 Other members listed at the end of the paper.

Correspondence W. T. Caiaffa Faculdade de Medicina, Universidade Federal de Minas Gerais. Av. Alfredo Balena 190, Belo Horizonte, $M G$ 30130-100, Brasil. wcaiaffa@medicina.ufmg.br
}

\begin{abstract}
This paper presents AIDS incidence and mortality among injecting drug users (IDUs) reached by the AjUDE-Brasil II Project. From a cross-sectional survey, 478 IDUs were interviewed in three Brazilian cities: Porto Alegre, São José do Rio Preto, and Itajaí. The cohort was followed up in the Brazilian surveillance database for AIDS and mortality during 2000 and 2001. AIDS incidence was 1.1 cases per 100 person-years, and the mortality rate was 2.8 deaths per 100 person-years. AIDS cases only occurred in IDUs who reported ever having shared injecting equipment. Female gender $(R R=5.30)$, homelessness $(R R=6.16)$, and report of previous sexual relations with same-sex partners $(R R=6.21)$ were associated with AIDS. Deaths occurred only among males. Homelessness $(R R=3.00)$, lack of income ( $R R=2.65)$, HIV seropositive status $(R R=4.52)$, and no history of incarceration $(R R=3.71)$ were also associated with death. These findings support evidence that gender and socioeconomic conditions are both determinants of morbidity and mortality in Brazilian IDUs.
\end{abstract}

Acquired Immunodeficiency Syndrome; Mortality; Intravenous Substance Abuse

\section{Introduction}

In Brazil, of the 362,363 AIDS cases reported to the Ministry of Health through the National Reportable Diseases System (SINAN) from 1980 to June $30,2004,16.4 \%$ were attributed to injecting drug use 1 .

Despite the downward trend in the proportion of new AIDS cases associated with injecting drug use, this decrease has not been homogeneous in the country. In some cities or regions, especially in the South, injecting drug users (IDUs) constitute an important component of the epidemic. In the southernmost State capital city, Porto Alegre, HIV prevalence among IDUs has reached $65 \% 2,3$.

For the year 2003, overall AIDS incidence in the Brazilian population was 18.4 cases per 100 thousand inhabitants. The epidemic is increasing more quickly in population groups with less schooling and lower socioeconomic status 4,5,6, and IDUs have been the group with the worst socioeconomic situation since the beginning of the epidemic 7 .

The incidence of HIV infection among IDUs, estimated at 1 to 3 per 100 person-years in the United States in the early 1990s, also appears to have dropped to some 1.84 per 100 personyears in 1995-1998 8,9. The known risk factors for HIV infection and the development of AIDS in this group are frequency of injection, sharing of needles and syringes, cocaine injecting, 
and sexual behaviors such as same-sex relations and sex with other IDUs 8.

In addition to representing an important risk group for HIV infection, IDUs are included in the portion of the population most exposed to increased mortality risk. Not only in Brazil, but elsewhere in the world, high mortality rates have been shown in this group, estimated at 3.3 deaths per 100 person-years in the United States in 1999-2000 10 and 2.3 deaths per 100 personyears in Edinburgh, Scotland, in 1980-2001 11.

The most relevant risk factors associated with death in IDUs are infectious diseases, especially AIDS and its markers such as high HIV viral load and decreased CD4 lymphocyte counts. Although the causes related to HIV disease currently constitute the principal cause of death in this population, there are other major causes of death, especially those related to overdose, pneumonia, and bacterial endocarditis, in addition to external causes such as suicide and homicide 10,11,12,13.

The current study aimed to estimate AIDS incidence and mortality among IDUs in the context of syringe-exchange programs (SEP) participating in the AjUDE-Brasil II Project, as well as to explore the principal determinants of these events.

\section{Method}

The AjUDE-Brasil II Project, a cross-sectional study conducted from May 2000 to February 2001, interviewed clients of SEP supported by the Drugs and AIDS Unit of the Programa Nacional de DST e AIDS, Ministry of Health (PNDST/AIDS). This study aimed to characterize the socio-demographic, behavioral, and serological profiles of the accessed IDUs. Structured interviews were conducted by properly trained staff and/or outreach workers. Collected information included social, sexual, and drug-use behavior, characteristics of the healthcare utilization and drug-related treatment, and any criminal record. Blood samples were collected by finger stick on filter paper to determine the HIV seroprevalence, using the ELISA test performed by two independent methods. The use of ELISA as a serological test was justified by the high HIV seroprevalence in the IDUs population and consequently by the tests' high positive predictive value 14 .

This prospective component study included three of the six Brazilian cities from the overall project: Porto Alegre in the State of Rio Grande do Sul, São José do Rio Preto in São Paulo, and Itajaí in Santa Catarina. These three cities were chosen because they presented structured SEP at the time the research was done, and because their respective city health departments allowed access to the local surveillance systems.

The 478 individuals interviewed in these cities constituted a cohort, followed up during the years 2000 and 2001, aimed at estimating AIDS incidence and mortality. The information gathered in the survey's baseline was used for the exposure variables. Identification of AIDS cases and deaths was based on a list of IDUs interviewed at baseline in the AjUDE-Brasil II Project, containing full name, date of birth, and mother's initials, allowing an active search of these individuals in the databases of the National Reportable Diseases System for AIDS (SINAN-AIDS) and the Mortality Information System (SIM) at the regional level. Information on incarceration was collected from local prison records.

Based on identification of the interviewee in the data systems, data on AIDS diagnosis and/or death were recorded, along with the respective underlying cause. Incident AIDS cases $(n=6)$ were defined as all IDUs found in the SINAN-AIDS database from May 10, 2000, to December 31, 2001, and who had not been recorded with a date prior to the interview during the field study in the AjUDE-Brasil II Project. Six additional individuals recorded in the SINAN-AIDS database during this same period, but who had the same date of death recording in the SIM (recorded in SINAN-AIDS following death) were not tabulated as incident cases because they were considered cases of delayed reporting. Fifty-six AIDS cases showed date of diagnosis prior to the beginning of the study and were considered prevalent AIDS cases and were excluded, such that 422 individuals remained. Individuals not found in the SINAN-AIDS database were considered AIDSfree.

Deaths $(n=17)$ were defined as all IDUs found in the SIM from May 10, 2000, to December 31, 2001, out of the total of 478 individuals interviewed.

As for the variables analyzed: age was dichotomized using as the cutoff point the natural number closest to the median; married IDUs or those living with a companion were classified as living in a marital union, while single, divorced/separated, and widow(ers) were classified as living alone. Sexual risk was defined as any reported sexual relations without a condom in the previous six months, regardless of the type (homosexual or heterosexual). The remaining information was obtained from 
direct responses by IDUs to the AjUDE-Brasil II Project questionnaire.

A descriptive analysis of the 478 study participants was performed initially using univariate analysis, by comparison of the incidence density rates between the exposed and unexposed groups, using the Poisson regression technique 15. Estimation of the relative risk used the risk ratio (RR) and respective 95\% confidence interval (95\%CI). Associations were also investigated for the exposure variables using chi-square $\left(\chi^{2}\right)$ or Fisher's exact test, as appropriate 16. Graphs using the Kaplan-Meier technique were produced to visualize the survival trend of IDUs between the field testing and the AIDS diagnosis 17 . Epidemiologically relevant exposure factors or those with a $p$-value of $\leq 0.20$ were selected for multivariate analysis using the Cox proportional model, aimed at producing a model adjusted for confounding variables 18 . Due to the model's limitations, variables with null incidence in one of the exposure categories were not included in this stage of the analysis.

The research complied with the guidelines and technical standards as defined by Ruling 196/96, and was approved by the Institutional Review Board of the Universidade Federal de Minas Gerais, case review ETIC 168/99.

\section{Results}

Of the 478 participating IDUs, $52.9 \%$ were from Porto Alegre, 26.8\% from São José do Rio Preto, and the remaining $20.3 \%$ from Itajaí. Mean age was $30.0 \pm 8.7$ years. Median schooling was five years (5th grade of primary school).

Table 1 shows the descriptive analysis of the IDUs. Most of the sample consisted of male IDUs, living alone. The majority of the IDUs reported having some source of income, although many were unemployed.

More than half of the IDUs reported not having sought drug-related or health treatment in the previous six months, and only one-fourth had used SEP services. Half were HIV-positive according to the field testing. Most had started using drugs after the age of 14, and by 18 years approximately half were already using injecting drugs. More than half of the IDUs were already sharing needles and syringes in some way.

Sexual initiation had occurred around 14 years of age, and some one-third reported any lifetime same-sex relations $35.2 \%$ of the males and $14.7 \%$ of the females). The vast majority had a history of police arrest, and nearly half had served prison time, with a median of a month and a half.
Table 1

Selected characteristics of 478 injecting drug users participating in a prospective component study of the AjUDE-Brasil II Project, 2000-2001.

\begin{tabular}{|c|c|c|}
\hline Characteristics & $\mathbf{n}$ & $\%$ \\
\hline \multicolumn{3}{|l|}{ Demographic } \\
\hline Male gender & 376 & 78.7 \\
\hline Lives alone & 305 & 63.8 \\
\hline Age $<30$ years & 248 & 51.9 \\
\hline Skin color white & 266 & 55.8 \\
\hline Can read & 417 & 87.2 \\
\hline No source of income* & 59 & 12.8 \\
\hline Unemployed* & 384 & 82.2 \\
\hline Homeless* & 122 & 25.7 \\
\hline \multicolumn{3}{|l|}{ Health conditions } \\
\hline HCV-positive & 294 & 61.5 \\
\hline HIV-positive & 235 & 49.2 \\
\hline Drug-related treatment* & 84 & 17.7 \\
\hline Health treatment* & 190 & 40.3 \\
\hline Currently in treatment for HIV/AIDS* & 75 & 16.1 \\
\hline HIV test (lifetime) & 272 & 56.9 \\
\hline Lifetime use of harm reduction project services & 124 & 25.9 \\
\hline \multicolumn{3}{|l|}{ Drug behavior } \\
\hline Age at initiation of drug use $<14$ years & 189 & 39.5 \\
\hline Age at initiation of injecting drug use $<18$ years & 235 & 49.2 \\
\hline Injecting drug use* & 364 & 76.2 \\
\hline Frequency of injection ( $>3$ times a day) ${ }^{\star}$ & 37 & 7.7 \\
\hline Lifetime sharing of injecting equipment (passive) & 259 & 55.5 \\
\hline Lifetime sharing of injecting equipment (active) & 285 & 60.8 \\
\hline Use of alcoholic beverages* & 428 & 89.7 \\
\hline Smoking* & 405 & 84.7 \\
\hline Marijuana* & 398 & 83.3 \\
\hline Sniffed cocaine* & 336 & 70.6 \\
\hline Crack* $^{*}$ & 221 & 46.5 \\
\hline \multicolumn{3}{|l|}{ Sexual behavior } \\
\hline Age at sexual debut $<14$ years & 199 & 41.6 \\
\hline Any lifetime same-sex sexual relations & 264 & 55.7 \\
\hline Sexual risk: unprotected sex* & 90 & 19.4 \\
\hline Report of genital lesions or discharge* & 143 & 30.1 \\
\hline \multicolumn{3}{|l|}{ Lifetime social behavior } \\
\hline Police arrest & 370 & 80.2 \\
\hline Convicted or served time & 209 & 45.7 \\
\hline Drug-related assault and aggression & 218 & 47.7 \\
\hline
\end{tabular}

Unknown information varied from $1(0.2 \%)$ to 45 (9.4\%).

* Information refers to previous six months. 
Mean follow-up time for analysis of AIDS incidence was 1.29 years (15.5 months). The AIDS incidence density for the entire group of IDUs was 1.10 cases per 100 person-years $(\mathrm{n}=$ 6), with 1.07 in Porto Alegre $(n=3), 1.42$ in São José do Rio Preto $(n=2)$, and 0.81 in Itajaí $(n=$ $1)$. There was no statistical difference between these rates in the three cities $(\mathrm{p}=0.680)$. Considering only HIV-positive individuals according to the ELISA test, the incidence was 2.54 per 100 person-years.

For mortality, the follow-up time was 1.28 years (15.4 months). The mortality rate was 2.77 deaths per 100 person-years. The rates by city were 1.16 per 100 person-years in São José do Rio Preto $(\mathrm{n}=2)$ and $1.56(\mathrm{n}=2)$ in Itajaí, while Porto Alegre showed the highest mortality at $4.16(\mathrm{n}=13)$, with a different statistical behavior from the other two cities ( $p=0.047$ ). The most common underlying cause of death was HIV disease $(66.7 \%, \mathrm{n}=10)$, followed by aggression $(20 \%, n=3)$, septicemia $(6.7 \%, n=1)$, and pneumonia $(6.7 \%, \mathrm{n}=1)$. Death from pneumonia occurred in one individual with an AIDS diagnosis according to the SINAN-AIDS database. Two deaths in São José do Rio Preto were classified as due to undefined conditions, but one of these was located with an AIDS diagnosis in the SINAN-AIDS database.

One individual had an AIDS diagnosis and died after the interview, while the death occurred three and a half months after the AIDS diagnosis recorded in the SINAN-AIDS. Another 12 IDUs who died were also found in the SINAN records: six had the same date for diagnosis and death, while six presented a date of diagnosis prior to the survey, with the death occurring some two years after recording of the AIDS diagnosis (mean 1.98 years, median 2.11 years).

\section{Univariate analysis}

\section{a) AIDS incidence}

Table 2 shows the main results. Of the six new AIDS cases, two were women, and although this was not statistically significant, they showed twice the risk of developing AIDS as compared to men. Homeless individuals had six times the risk of developing the syndrome. The influence of one's living place on survival of IDUs with AIDS can be seen in Figure 1, showing a statistically lower survival function for homelessness (log-rank $=5.75 ; \mathrm{p}=0.016$ ).

All of the six new AIDS cases had previous HIV-positive serology and reported ever having shared needles and/or syringes. Individuals who sought health treatment were associated with a higher risk of developing AIDS as compared to those who did not seek health treatment. There was no significant difference in the risk of developing AIDS, when comparing those who sought or failed to seek drug-related treatment. All of the AIDS cases reported previous use of SEP services, although this was not statistically significant.

As for sexual exposure, individuals reporting any lifetime same-sex relations, all of whom were male, showed a fivefold risk of developing AIDS as compared to those denying such exposure. Paradoxically, those who reported adequate condom use showed a six-fold risk of having an AIDS diagnosis. Likewise, individuals who reported not having used cocaine in the previous six months showed a greater risk of AIDS diagnosis as compared to those reporting use of this drug during the same period. Although the association was not significant $(\mathrm{p}=$ 0.561 ), the RR point estimate indicated a more than fivefold risk in the group of individuals who self-identified as non-cocaine users $(\mathrm{RR}=$ 5.26 ; $95 \% \mathrm{CI}=0.96-33.33$ ).

In order to elucidate these findings, a parallel analysis of some exposure variables was performed in the prevalent cases found in the SINAN-AIDS database. Of the 56 prevalent cases, $16.2 \%$ of those reporting condom use in all their sexual relations already had an AIDS diagnosis in the SINAN-AIDS, as compared to $8.3 \%$ in the group reporting irregular condom use $(p=0.008)$. Likewise, in the group that had not used cocaine in the six months prior to the interview, $16.4 \%$ already had an AIDS diagnosis in SINAN-AIDS, as compared to $9.8 \%$ in the group who reported cocaine use $(p=0.04)$. In addition, the group that attended SEP services had $15 \%$ of its IDUs with an AIDS diagnosis in the SINAN-AIDS, while only $2.4 \%$ of those not attending SEP services were found in the SINAN-AIDS $(\mathrm{p}<0.001)$

\section{b) Mortality}

All of the 17 deaths occurred in males who reported not having sought drug-related treatment in the previous six months (Table 3). Other demographic characteristics associated with death were: not living in a marital relationship, not having any source of income in the previous six months, and homelessness in the previous six months. Figure 1 shows a comparative survival curve for IDUs, stratified by homelessness. Statistically distinct probabilities are observed for this event as compared to the group with a living place $(\log$-rank $=4.29, \mathrm{p}=0.04)$. 
AIDS incidence according to selected characteristics of 422 injecting drug users participating in prospective component study of the AjUDE-Brasil II Project, 2000-2001.

\begin{tabular}{|c|c|c|c|c|c|}
\hline & $\mathbf{n}$ & Rate* & $p$ & $\mathbf{R R}$ & $95 \% \mathrm{Cl}$ \\
\hline \multicolumn{6}{|l|}{ Gender } \\
\hline Male & 4 & 0.92 & & 1.00 & \\
\hline Female & 2 & 1.87 & 0.410 & 2.04 & $0.37-7.82$ \\
\hline \multicolumn{6}{|l|}{ Age (years) } \\
\hline$<30$ & 3 & 1.00 & & 1.00 & \\
\hline$\geq 30$ & 3 & 1.22 & 0.808 & 1.22 & $0.25-6.04$ \\
\hline \multicolumn{6}{|l|}{ Skin color } \\
\hline White & 3 & 0.98 & & 1.00 & \\
\hline Non-white & 3 & 1.27 & 0.753 & 1.30 & $0.26-6.25$ \\
\hline \multicolumn{6}{|l|}{ Marital status } \\
\hline Married & 1 & 0.51 & & 1.00 & \\
\hline Single & 5 & 1.44 & 0.346 & 2.80 & $0.32-24.02$ \\
\hline \multicolumn{6}{|c|}{ Source of income } \\
\hline Yes & 5 & 1.10 & & 1.00 & \\
\hline No & 1 & 1.56 & 0.754 & 1.41 & $0.16-12.06$ \\
\hline \multicolumn{6}{|l|}{ Living place } \\
\hline Yes & 2 & 0.49 & & 1.00 & \\
\hline No & 4 & 2.96 & 0.039 & 5.99 & $1.09-32.70$ \\
\hline \multicolumn{6}{|l|}{ HIV } \\
\hline Negative & 0 & 0.00 & & - & \\
\hline Positive & 6 & 2.54 & 0.006 & - & - \\
\hline \multicolumn{6}{|c|}{ Health treatment } \\
\hline Yes & 5 & 2.54 & 0.049 & 8.33 & $1.01-71.43$ \\
\hline No & 1 & 0.30 & & 1.00 & \\
\hline \multicolumn{6}{|c|}{ Drug-related treatment } \\
\hline Yes & 1 & 1.09 & & 1.00 & \\
\hline No & 5 & 1.12 & 0.981 & 1.03 & $0.12-8.79$ \\
\hline \multicolumn{6}{|c|}{$\begin{array}{l}\text { Ever used syringe-exchange } \\
\text { program services }\end{array}$} \\
\hline Yes & 6 & 1.52 & 0.189 & - & - \\
\hline No & 0 & 0.00 & & - & \\
\hline \multicolumn{6}{|l|}{ Sexual risk } \\
\hline Absent & 5 & 2.21 & 0.078 & 6.71 & $0.78-57.47$ \\
\hline Present & 1 & 0.32 & & 1.00 & \\
\hline \multicolumn{6}{|c|}{ Same-sex sexual relations } \\
\hline No & 2 & 0.56 & & 1.00 & \\
\hline Yes & 4 & 2.47 & 0.075 & 4.68 & $0.86-25.54$ \\
\hline \multicolumn{6}{|c|}{ Ever served time in prison } \\
\hline No & 2 & 0.68 & & 1.00 & \\
\hline Yes & 4 & 1.77 & 0.267 & 2.61 & $0.48-14.26$ \\
\hline
\end{tabular}

* Rate calculated by Poisson regression. 
Figure 1

Probability of AIDS and death among IDUs participating in the AjUDE-Brasil II Project, 2000-2001, using the Kaplan-Meier method stratified by living condition.
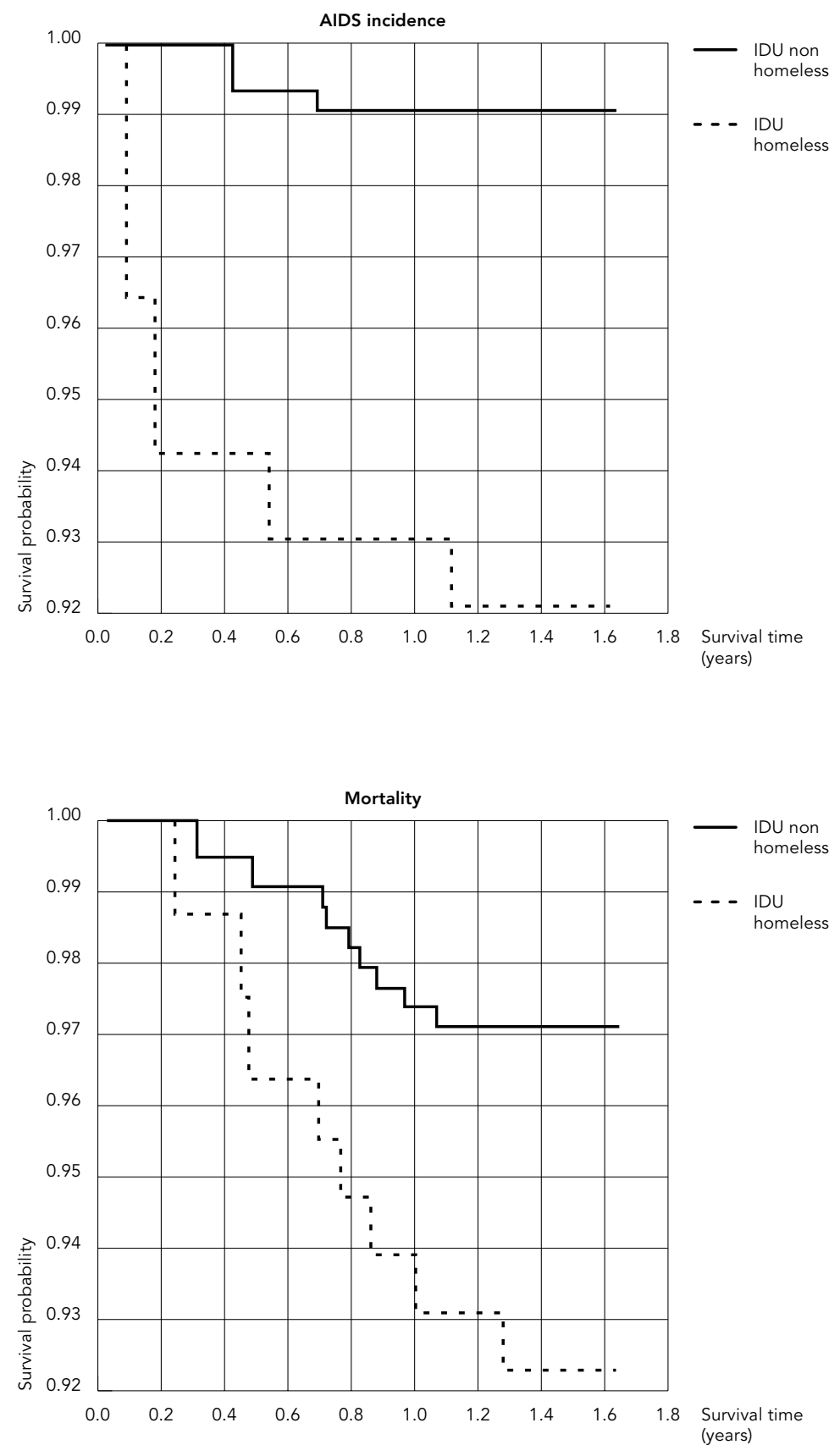

HIV-positive individuals showed increased risk of death. Prior AIDS diagnosis in the SINANAIDS database was an important predictor of death. Individuals with the syndrome showed a 20 -fold risk of dying.

As for criminal records, in the univariate analysis the absence of previous incarceration or conviction did not significantly increase the risk of dying. However, analyzing only males, the RR increased to $2.04(\mathrm{p}=0.158)$. In order to better understand this characteristic, we investigated the association between AIDS recorded in the SINAN-AIDS and reported history of conviction. The proportion of AIDS cases doubled when comparing IDUs without criminal records $(8.1 \%)$ to those with criminal records $(16.7 \%)(p=0.004)$. As for frequency of arrests, among males reporting only one arrest, $14.8 \%$ were recorded with AIDS in the SINAN-AIDS. Among male IDUs with more than one arrest, the proportion was significantly higher $(28.6 \%$; $\mathrm{p}=0.089$ ).

\section{Multivariate analysis}

Table 4 shows the results of this analysis for the two target events.

New AIDS cases occurred independently with increased probability among IDUs who reported homelessness in the six months prior to the interview, in female IDUs, and in those with any lifetime report of same-sex sexual relations.

A model was investigated that included the six AIDS cases with a simultaneous report of death, classified here as delayed reporting. The results generated a model that was very similar to the multivariate model for mortality and is described below.

In relation to mortality analysis, considering that all the deaths occurred in males, we opted to use the 376 male IDUs to comprise this stage of the analysis. The types of exposure that were markers for socioeconomic status and that remained in the model after adjusting and were statistically significant were homelessness and lack of income, increasing the risk of death by some threefold. Positive HIV serology increased the risk of death fivefold, while time served in some penal institution decreased the risk of death. IDUs who reported never having been incarcerated showed a fourfold greater risk of dying as compared to those with a history of conviction.

Analysis of the Martingale and Deviance residues 18 were performed for all the multivariate models, showing good adequacy and adjustment in the final models. 
Mortality rates according to selected characteristics of 478 injecting drug users participating in the prospective component project of the AjUDE-Brasil II Project, 2000-2001.

\begin{tabular}{|c|c|c|c|c|c|}
\hline & $\mathbf{N}$ & Rate* $^{*}$ & $p$ & RR & $95 \%$ IC \\
\hline \multicolumn{6}{|l|}{ Gender } \\
\hline Male & 17 & 3.52 & 0.030 & - & \\
\hline Female & 0 & 0.00 & & - & - \\
\hline \multicolumn{6}{|l|}{ Age (years) } \\
\hline$<30$ & 8 & 2.56 & & 1.00 & \\
\hline$\geq 30$ & 9 & 3.00 & 0.746 & 1.17 & $0.45-3.03$ \\
\hline \multicolumn{6}{|l|}{ Skin color } \\
\hline White & 10 & 2.85 & 0.903 & 1.06 & $0.40-2.79$ \\
\hline Non-white & 7 & 2.68 & & 1.00 & \\
\hline \multicolumn{6}{|l|}{ Marital status } \\
\hline Married & 2 & 0.92 & & 1.00 & \\
\hline Single & 15 & 3.83 & 0.058 & 4.16 & $0.95-18.21$ \\
\hline \multicolumn{6}{|c|}{ Source of income } \\
\hline Yes & 11 & 2.15 & & 1.00 & \\
\hline No & 5 & 6.56 & 0.039 & 3.05 & $1.06-8.77$ \\
\hline \multicolumn{6}{|l|}{ Living place } \\
\hline Yes & 9 & 1.99 & & 1.00 & \\
\hline No & 8 & 5.08 & 0.054 & 2.55 & $0.98-6.60$ \\
\hline \multicolumn{6}{|l|}{ HIV } \\
\hline Negative & 3 & 0.98 & & 1.00 & \\
\hline Positive & 14 & 4.57 & 0.016 & 4.65 & $1.34-16.19$ \\
\hline \multicolumn{6}{|c|}{ In AIDS database (SINAN) } \\
\hline No & 5 & 0.92 & & 1.00 & \\
\hline Yes & 12 & 17.74 & $<0.001$ & 19.35 & $6.82-54.92$ \\
\hline \multicolumn{6}{|c|}{ Drug-related treatment } \\
\hline Yes & 0 & 0.00 & & - & \\
\hline No & 17 & 3.41 & 0.052 & - & - \\
\hline \multicolumn{6}{|c|}{$\begin{array}{l}\text { Ever used syringe-exchange } \\
\text { program services }\end{array}$} \\
\hline Yes & 15 & 3.25 & 0.230 & 2.47 & $0.56-10.79$ \\
\hline No & 2 & 1.32 & & 1.00 & \\
\hline \multicolumn{6}{|l|}{ Sexual risk } \\
\hline Absent & 10 & 3.70 & 0.238 & 1.79 & $0.68-4.70$ \\
\hline Present & 7 & 2.07 & & 1.00 & \\
\hline \multicolumn{6}{|c|}{ Same-sex sexual relations } \\
\hline No & 13 & 4.24 & 0.316 & 1.79 & $0.58-5.48$ \\
\hline Yes & 4 & 2.37 & & 1.00 & \\
\hline \multicolumn{6}{|c|}{ Ever served time in prison } \\
\hline No & 11 & 3.51 & 0.352 & 1.60 & $0.59-4.34$ \\
\hline Yes & 6 & 2.19 & & 1.00 & \\
\hline
\end{tabular}

* Mortality rate calculated by Poisson regression. 
AIDS incidence density ratio and adjusted mortality ratio using Cox regression method for injecting drug users participating in the AjUDE-Brasil II Project, 2000-2001.

\begin{tabular}{|c|c|c|c|c|}
\hline & Estimate & Risk Ratio & $95 \% \mathrm{Cl}$ & $\mathrm{p}$ \\
\hline \multicolumn{5}{|l|}{ AIDS incidence* } \\
\hline Female gender & 1.67 & 5.30 & $0.78-36.08$ & 0.088 \\
\hline Homelessness & 1.82 & 6.16 & $1.07-35.31$ & 0.041 \\
\hline Same-sex sexual relations & 1.82 & 6.21 & $0.95-40.62$ & 0.057 \\
\hline \multicolumn{5}{|l|}{ Mortality } \\
\hline Lack of income & 0.97 & 2.65 & $0.98-7.17$ & 0.055 \\
\hline Homelessness & 1.09 & 3.00 & $1.01-8.73$ & 0.047 \\
\hline Positive HIV serology & 1.51 & 4.52 & $1.26-16.21$ & 0.021 \\
\hline Lack of incarceration (lifetime) & 1.31 & 3.71 & $1.26-10.94$ & 0.018 \\
\hline
\end{tabular}

*Comparisons relating to the same categories as in the univariate analysis.

\section{Discussion}

In this study, Brazilian IDUs showed AIDS incidence and death rates greater than $1 \%$ and $2 \%$ per year, respectively. AIDS risk was associated with sharing of needles and/or syringes, female gender, same-sex sexual relations, and precarious living conditions, as marked here by homelessness in the previous six months. Death, which occurred only among males and with higher risk among those with an HIV/AIDS diagnosis, was also associated with precarious living conditions and possible lost opportunities for diagnosis and treatment, as marked here by the absence of time served in a penal institution.

The few Brazilian and international studies on this issue show rate estimates similar to those found here. There is a similarity between the AIDS incidence estimate and the HIV infection rates of 1 to 3 cases per 100 person-years found currently in the United States 9 . In addition, comparing the mortality estimates with contemporary international studies, one notes some similarity in the rates, varying from 2.8 to 3.3 per 100 person-years, despite the methodological differences between the studies 10,11.

The finding that women showed increased AIDS risk appears consistent with the epidemic's overall profile in Brazil, currently with 18.8 AIDS cases per 100 thousand inhabitants. Contrary to the situation described for men, in whom the epidemic shows signs of stabilization, among women, with 14 new cases per 100 thousand, the figures show an upward annual trend. These data appear to confirm the hypothesis that women are becoming more vulnera- ble to AIDS in Brazil 1,19. For female IDUs, this appears to be a typically Brazilian phenomenon, since international studies point to lower risk of progression to AIDS among women IDUs 20. Absence of deaths in female IDUs in the current study could reflect the peculiar dynamic of the HIV/AIDS epidemic, which is more mature among males (the predominant gender in the early days of the epidemic among IDUs) and who would thus tend to show an increased risk of death.

The importance of socioeconomic indicators can be observed in IDUs morbidity and mortality. Major risk factors were homelessness and lack of income, associated with both AIDS and death. This agrees with international studies showing a fivefold mortality risk in IDUs with no source of income 21 . These data appear to confirm the pauperization of the HIV/AIDS epidemic and its negative outcomes in Brazil 4 and also prove this population group's vulnerability and the importance of maintaining IDUs as targets in the main prevention programs.

Corroborating the above is the confirmation that sharing of needles and/or syringes is one of the principal risk factors for AIDS, reinforcing the importance of preventive measures, especially in the less privileged segments of this population group, in order to inhibit injecting practices with contaminated equipment.

Probable evidence of the above is the association between use of SEP services and increased AIDS incidence. In the current study, as well as in international research such as that of Bruneau et al. 22, this association suggests that SEP in the respective cities are accessing a segment of IDUs in precarious living and health 
conditions, the majority of whom are HIV-positive and who come to treatment services late, when they already present the initial symptoms of the disease 23 . While some might question whether SEP are meeting the role of primary prevention and health promotion, that is, before HIV infection, these data do suggest that SEP are satisfactorily meeting their role in secondary and tertiary prevention.

Still, the underlying cause in the majority of deaths was HIV infection and AIDS. That is, HIV/ AIDS is confirmed as cause of death in a young segment of the Brazilian population, although external causes cannot be overlooked 10,24.

Two findings in this study are intriguing: $100 \%$ of the deaths occurred in individuals who reported not having sought drug-related treatment, and there was a lower risk of death among those who reported having served time in a penal institution. One hypothesis is that these data point to direct or indirect participation by health care services for vulnerable groups, whether at the primary or specialized level, for example in prisons, suggesting that IDUs who are more exposed to such services have a higher probability of both diagnosis (as evidenced in this study by the higher proportion of AIDS cases recorded in the SINAN-AIDS database among IDUs who reported having served time in prison) and treatment, consequently showing decreased odds of death, principally related to HIV/AIDS.

This hypothesis is consisted with the work by Havens et al. 25, whose IDUs cohort study showed an association between the search for psychiatric treatment and decreased mortality. Mental health services or those provided by prisons and which focus on overcoming the dichotomy between treatment and prevention 26 could function as possible markers for the reduction in mortality, due to increased access to HIV/AIDS diagnosis and treatment.

The current study has limitations. One of them is the small number of events collected in the short follow-up period, possibly jeopardizing the relative risk estimates, which failed to reach significance due to lack of statistical power. We thus classified some statistical associations as significant when the $\mathrm{p}$ values were either borderline or slightly above 0.05 . The IDUs would have to be followed up for a longer period of time in order to accumulate more cases and better elucidate the risk factors for morbidity and mortality in this group.

The incidence and mortality rates found here may be lower than expected, due to underreporting in the surveillance systems (for example, $42.7 \%$ in the SINAN-AIDS database in the city of Rio de Janeiro) 27. Corroborating this possibility, in the current study six AIDS cases among IDUs were entered into the SINANAIDS database at the time of death, thus suggesting a reporting delay of some $50 \%$. The AIDS incidence rates may therefore be twice what were actually shown here.

It is also conceivable that there was an underestimation of deaths (in the SIM) due to delayed reporting, given that classification problems are common, as described in studies in Rio de Janeiro and Belo Horizonte 27,28. In addition, underestimation could occur due to high co-morbidity and mortality from competing causes in this IDUs group 29,30.

Another important limitation of this study is the presence of a prevalence bias. To analyze AIDS incidence, some exposure variables that represent classic risk factors for AIDS behave as protective factors. We hypothesize that individuals with symptoms prior to their AIDS diagnosis could reverse their risk behavior. This could explain the threefold risk of AIDS among those reporting some type of medical treatment in the previous six months, as compared to those without treatment. The lower use of sniffed cocaine in the incident AIDS group could also indicate that individuals with the syndrome decrease their drug use as the disease progresses.

The same bias would also appear to explain the increased AIDS risk among individuals reporting adequate condom use. Since they are aware of their serological status or display symptoms of the disease, they probably report more frequent condom use.

Further research is necessary to confirm the determinants of morbidity and mortality that were shown by the current study in IDUs. Despite this study's limitations, we highlight the importance of AIDS in the life and death of injecting drug users and can expect that the IDUs studied here are living in precarious living and health conditions, with considerable vulnerability to HIV/AIDS.

Measures taken in the future to improve the control of the HIV/AIDS epidemic in this group should include both specific prevention strategies for IDUs and better access to diagnosis and treatment, with a strong emphasis on SEP as one of the most effective mechanisms for accessing this difficult-to-reach group. 


\section{Resumo}

Este estudo apresenta a incidência de AIDS e a mortalidade em usuários de drogas injetáveis (UDIs) participantes do Projeto AjUDE-Brasil II. Uma coorte de 478 indivíduos entrevistados nas cidades de Porto AlegreRio Grande do Sul -, São José do Rio Preto - São Pauloe Itajaí - Santa Catarina - foi acompanhada nos sistemas de vigilância brasileiros entre 2000 e 2001. Encontrou-se incidência de AIDS de 1,1 caso por 100 pessoas/ano e taxa de mortalidade de 2,8 óbitos por 100 pessoas/ano. Casos de AIDS ocorreram somente em UDI que relataram compartilhar seringas. Sexo feminino $(R R=5,30)$, relato de ausência de local para morar $(R R=6,16)$ e de relações sexuais com pessoas do mesmo sexo $(R R=6,21)$ estiveram associados à ocorrência de AIDS. Relato de ausência de local para morar $(R R=3,00)$ e de fonte de renda $(R R=2,65)$, ser $H I V$ soropositivo $(R R=4,52)$ e nunca ter sido encarcerado $(R R=3,71)$ se associaram aos óbitos, que ocorreram somente em homens. Esses achados parecem confirmar que diferenças de gênero e condições econômicas são determinantes para a morbi-mortalidade de UDIs brasileiros.

Síndrome de Imunodeficiência Adquirida; Mortali dade; Uso Indevido de Drogas Parenterais

\section{Contributors}

M. N. Cardoso was responsible for the literature structuring of the database for data analysis, and drafting of the article. W. T. Caiaffa conducted literature searches, data analysis, and participated in drafting the article, especially in relation to discussion of the findings. S. A. Mingoti conducted literature searches (principally on scientific methodology), data analysis (supervision of the statistical techniques used in the article), and drafting of the sections on presentation and interpretation of the results.

\section{Other members of the AjUDE-Brasil II Project}

J. Andrade, T. Andrade, A. Brás, R. T. Caiaffa, I. Cardoso, M. Cardoso, R. Carmosina, A. B. Carneiro-Proietti, K. Casseb, M. A. Chagas, R. Coelho, M. Colombo, M. Decândio, S. F. Deslandes, I. L. Dias, D. Dominguez, D. Doneda, R. Eller, E. Ferreira, D. Gandolfi, G. Gomes, T. Grever, A. Guimarães, P. Güths, M. Hacker, N. Januário, R. Junkes, R. Knoll, A. Lopes, D. Lisboa, M. Lopes, Â. Maia, M. Malta, R. Marinho, C. Martins, D. Matos, R. Mayer, S. Mello, H. Mendes, E. Mendonça, J. Moreira, A. C. Oliveira, D. Padilha, A. Paixão, I. Picinim, F. Proietti, P. Reis, C. Rinaldi, R. Rosa, V. Rodrigues, E. Santos, M. Santos, A. M. Silva, R. Silva, I Silva, F. Silva, G. Strossi, M. Sudbrack, S. Tomaz, T. Telles, M. Urço, W. Vargas Jr.

\section{Acknowledgments}

This study was conducted by the Universidade Federal de Minas Gerais, with technical and financial support from the Cooperative Project between the Programa Nacional de DST e AIDS and the United Nations Office on Drugs and Crime (UNODC), no. AD/ BRA/99/EO2.

\section{References}

1. Ministério da Saúde. Boletim Epidemiológico AIDS e DST 2004; ano I, n. 1. http://www.aids. gov.br/final/dados/BOLETIM2.pdf (accessed on 02/Dec/2004).

2. Caiaffa WT, Proietti FA, Carneiro-Proietti AB, Mingoti SA, Doneda D, Gandolfi D, et al. Projeto AjUDE-Brasil II: avaliação epidemiológica dos usuários de drogas injetáveis dos projetos de redução de danos apoiados pelo PN-DST/AIDS. Brasília: Ministério da Saúde; 2003.

3. Caiaffa WT, Proietti FA, Carneiro-Proietti AB, Mingoti SA, Doneda D, Gandolfi D, et al. The dynamics of the Human Immunodeficiency Virus epidemics in the South of Brazil: increasing role of injection drug users. Clin Infect Dis 2003; 37 Suppl 5:S376-81.

4. Bastos FI, Szwarcwald CL. AIDS e pauperização: principais conceitos e evidências empíricas. Cad Saúde Pública 2000; 16 Suppl 1:65-76.

5. Fonseca MG, Bastos FI, Derrico M, Andrade CL, Travassos C, Szwarcwald CL. AIDS e grau de escolaridade no Brasil: evolução temporal de 1986 a 1996. Cad Saúde Pública 2000; 16 Suppl 1:77-87.

6. Fonseca MGP, Szwarcwald CI, Bastos FI. Análise sociodemográfica da epidemia de Aids no Brasil, 1989-1997. Rev Saúde Pública 2002; 36:678-85.

7. Fonseca MGP, Travassos C, Bastos FI, Silva NV Szwarcwald CL. Distribuição social da AIDS no Brasil, segundo participação no mercado de trabalho, ocupação e status sócio-econômico dos casos de 1987 a 1998. Cad Saúde Pública 2003; 19:1351-63.

8. Nelson KE, Galai N, Safaeian M, Strathdee SA, Celentano DD, Vlahov D. Temporal trends in the incidence of human immunodeficiency virus infection and risk behavior among injection drug users in Baltimore, Maryland, 1988-1998. Am J Epidemiol 2002; 156:641-53.

9. Vu MQ, Steketee RW, Valleroy L, Weinstock H, Karon J, Janssen R. HIV incidence in the United States, 1978-1999. J Acquir Immune Defic Syndr 2002; 31:188-201.

10. Vlahov D, Wang CL, Galai N, Bareta J, Mehta SH, Strathdee SA, et al. Mortality risk among new onset injection drug users. Addiction 2004; 99:94654.

11. Copeland L, Budd J, Robertson JR, Elton RA. Changing patterns in causes of death in a cohort of injecting drug users, 1980-2001. Arch Intern Med 2004; 164:1214-20.

12. Zaccarelli M, Gattari P, Rezza G, Conti S, Spizzichino L, Vlahov D, et al. Impact of HIV infection 
on non-AIDS mortality among Italian injecting drug users. AIDS 1994; 8:345-50.

13. van Ameijden EJ, Krol A, Vlahov D, Flynn C, van Haastrecht HJ, Coutinho RA. Pre-AIDS mortality and morbidity among injection drug users in Amsterdam and Baltimore: an ecological comparison. Subst Use Misuse 1999; 34:845-65.

14. Caiaffa WT, Proietti FA, Carneiro-Proietti AB, Mingoti SA, Doneda D, Gandolfi D, et al. Projeto AjUDE-Brasil. Avaliação epidemiológica dos usuários de drogas injetáveis dos projetos de redução de danos apoiados pelo PN-DST e AIDS. Brasília: Ministério da Saúde; 2001.

15. Frome EL. The analysis of rates using Poisson regression models. Biometrics 1983; 39:665-74.

16. Soares JF, Siqueira AL. Introdução à estatística médica. Belo Horizonte: Departamento de Estatística, Universidade Federal de Minas Gerais; 1999.

17. Bustamante-Teixeira MT, Faerstein E, Latorre MR. Técnicas de análise de sobrevida. Cad Saúde Pública 2002; 18:579-94.

18. Hosmer Jr. DW, Lemeshow S. Applied survival analysis: regression modeling of time to event data. New York: John Wiley \& Sons; 1998.

19. Vermelho LL, Barbosa RH, Nogueira SA. Mulheres com AIDS: desvendando histórias de risco. Cad Saúde Publica 1999; 15:369-79.

20. Garcia-de la Hera M, Ferreros I, del Amo J, Garcia-de Olalla P, Perez-Hoyos S, Muga R, et al. Gender differences in progression to AIDS and death from HIV seroconversion in a cohort of injecting drug users from 1986 to 2001. J Epidemiol Community Health 2004; 58:944-50.

21. Piketty C, Castiel P, Giral P, Lhomme JP, Boubilley D, Olievenstein C, et al. Lack of legal income is strongly associated with an increased risk of AIDS and death in HIV-infected injecting drug users. AIDS Care 1999; 11:429-36.

22. Bruneau J, Lamothe F, Franco E, Lachance N, Desy M, Soto J, et al. High rates of HIV infection among injection drug users participating in needle exchange programs in Montreal: results of a cohort study. Am J Epidemiol 1997; 146:994-1002.
23. Amill A, Gomez ML, Fernandez DM, Bangdiwala SI, Rios E, Hunter RF. Changing profiles of injecting drug users with AIDS in a Hispanic population. Addiction 2004; 99:1147-56.

24. Mezzelani P, Quaglio GL, Venturini L, Lugoboni F, Friedman SR, Des Jarlais DC. A multicentre study on the causes of death among Italian injecting drug users. AIDS has overtaken overdose as the principal cause of death. AIDS Care 1998; 10:61-7.

25. Havens JR, Strathdee SA, Fuller CM, Ikeda R, Friedman SR, Des Jarlais DC, et al. Correlates of attempted suicide among young injection drug users in a multi-site cohort. Drug Alcohol Depend 2004; 75:261-9.

26. Blower SM, Gershengorn HB, Grant RM. A tale of two futures: HIV and antiretroviral therapy in San Francisco. Science 2000; 287:650-4

27. Ferreira VMB, Portela MC. Avaliação da subnotificação de casos de Aids no Município do Rio de Janeiro com base em dados do sistema de informações hospitalares do Sistema Único de Saúde. Cad Saúde Pública 1999; 15:317-24.

28. Oliveira MTC, Caiaffa, WT, Mingoti AS, Silva R, Fernandez H, Macedo LM, et al. Underreporting of AIDS cases in Brazil: applications of capturerecapture methods. In: XIII International Aids Conference. Durban: International AIDS Conference; 2000. p. 378.

29. Caiaffa WT, Vlahov D, Graham NM, Astemborski J, Solomon L, Nelson KE, et al. Drug smoking, Pneumocystis carinii pneumonia, and immunosuppression increase risk of bacterial pneumonia in human immunodeficiency virus-seropositive injection drug users. Am J Respir Crit Care Med 1994; 150:1493-8.

30. Vlahov D, Fuller CM, Ompad DC, Galea S, Des Jarlais DC. Updating the infection risk reduction hierarchy: preventing transition into injection. J Urban Health 2004; 81:14-9.

Submitted on 26/Sep/2005

Final version resubmitted on 24/Nov/2005 Approved on 28/Nov/2005 